\title{
USE AND ABUSE OF THE 'MODERN' VERSUS 'TRADITIONAL' LAW DICHOTOMY IN SOUTH AFRICA
}

\author{
By S. B. BuRMAN
}

This paper is a discussion of the usefulness of the conceptual framework which, in dealing with disputes in multi-cultural societies, sees legal systems as divisible into a dichotomy of traditional or modern. Specifically, this paper deals with the usefulness of this conceptualisation in the South African situation, where it has been applied for over 100 years and where the effects of its use can now, to some extent, be assessed in a variety of situations. Its usefulness is therefore assessed in relation to its actual practical application in South African society, rather than to its academic merits as a means of categorising different ty pes of society. The criteria employed are whether the use of the dichotomy is a theoretical tool which enables the legal officers to understand better the nature of the disputes brought under African law; whether in the courts and legislature it enables the legal system to acknowledge the changing customs of a society undergoing extensive industrialisation; and whether it enables the country's policy makers to achieve other results they desire which would not be possible without this conceptualisation.

\section{Understanding disputes}

While it was of course recognised by the white settlers from the period of their first extensive contact with Africans in southern African that African societies lived by different rules to those observed by the settlers themselves, initial white reaction was to discount African rules altogether as a legal system. The first African tribes to come under white rule in southern Africa were in what is now the Cape Province and the Ciskei in the Republic of South Africa, and white magistrates were instructed to apply only the law of the Cape Colony. This was Roman-Dutch law, modified by English common law to some extent after the Cape had become an English colony earlier in the nineteenth century. However, it proved impossible to ignore African law totally when dealing with a polygamous society most of whose institutions were based on family relationships that Cape law refused to recognise as existing. As a result, when territories with much larger African populations came under British rule in the Colony of Natal, Basutoland (modern Lesotho) and the Transkei, policies that at least partially recognised African law were instituted. In each area a number of missionaries and administrators who were sympathetic to the Africans and most of their institutions were involved in the formation of the policies over many years. Some had grown up in the territories, spoke the languages of the tribes with which they dealt, and had a good understanding of how their institutions operated whithin those societies, but they were, of course, products of their own society too. A belief into he values of nineteenth century Victorian Christianity was incompatible with a belief that other societies might have an equally valid set of beliefs and way of life which need never converge with those of the colonisers. To judge from the writings of the administrators and missionaries of the period who played a major role in legal policy formation, it was axiomatic to them that there could exist only one hierarchy of legal systems, of which their own stood at the apex. Any other system was an inferior form developing towards the perfection of contemporary western legal systems. The basic legal institutions of any society could therefore be understood as imperfect forms of western institutions, the concepts of which would encapsulate the lesser varieties. 
This set of attitudes is still indicated by our contemporary terminology of 'traditional and modern legal systems', which implies that the traditional belong to the same hierarchy of legal systems as do the western, to be understood in the same conceptual framework, but that they are more backward than their modern $(=$ desirable) Counterparts. Many recent works on jurisprudence which mention 'traditional law' demonstrate this attidude (e.g. Paton 1951, Lloyd 1965). I do not propose to discuss the desirability - on whatever criteria - of western as against indigenous African traditional legal systems; the point of relevance to this discussion is the assumption inherent in the terminology that western concepts are the appropriate tools for an understanding of African legal systems. This point, and the parallel debate on the universality of economic principles (Cohen 1967), came to the attention of anthropologists some years ago. Gluckmann (1955, 1965a, 1965b) and Hoebel (1954) suggested that at least certain parts of western jurisprudence might provide a conceptual framework within which legal facts in a tribal society could be interpreted, while Bohanan (1963) argued that to understand any legal system it was necessary to graps from the inside the legal concepts of the society being studied. This dispute on how to structure anthropological findings on social order and conflict resolution has remained unresolved, but at a Wenner-Gren conference held in Austria in 1966 it was agreed by Gluckmann, Hoebel and Bohanan that a comparative analytical system was necessary for discussing different legal systems in various societies. They also agreed that western jurisprudence could not be used as this comparative analytical system, though to form it some western jurisprudential concepts (and those of other legal analytical systems, as well as sociological and anthropological concepts) could be drawn upon after the conceptual system of each society's legal system had been understood (Nader 1969). It is this position with which the terminology 'traditional and modern legal systems' is in conflict, since the terminology implies a pyramid at the apex of which are western jurisprudential concepts, seen as the most developed form of legal conceptualisation and suitable for use as a comparative analytical system. A less value-laden terminology is needed, although there are other problems with such obvious alternatives as 'indigenous' and 'western'.

The terminology also obviously represents a position in the unresolved debate on how best to create order in anthropological findings on any single tribal society, and has subtly propagated this set of ideas to both twentieth century colonial administrators and African lawyers. It is only now that lawyers who deal with African law, as well as anthropologists, are beginning to query the use of western concepts to cover those of African law, and very little detailed work has been done on their effect on the legal systems of African countries. However, at a seminar in Leiden in 1974 on 'New Directions in African Family Law' this point was raised in connection with marriage - a central feature in African law - and several people drew attention to the inadequacies of western law in this respect. Roberts, who edited a selection of papers from the seminar, in his introduction gave a very clear summary of some of the problems illustrated by the papers:

. . . 'marriage' as contemplated under English law and the law of most other modern western societies has some marked characteristics which can certainly not be treated as universal. For example, it is formed on an identifiable occasion, when all the rights potentially associated with it are acquired; it acquires validity through the ceremonial procedures associated with its formation; and it is clearly distinguished in terms of social approval and in terms of legal consequences forms less approved forms of mating. Thus, if marriage is approached from this standpoint there are involved assumptions as to the way in which marriage-type relationships come into being, as to the nature and importance of ceremonial procedures associated with formation, as to the manner in which 
'rights' are created and transferred in association with formation, and as to a distinction between approved and disapproved forms of mating and their relationship to one another ... Repeatedly, lawyers particularly, have come back to such questions as: 'At what point in time does marriage come into being in society?' 'What ceremonial procedures are essential to its formation?' Yet there is now a growing body of data indicating that these questions are inappropriate. First, in many African societies 'marriage' does not come into being on some clearly defined occasion, but is formed slowly over time (e.g. Evans-Pritchard 1951; Kuper 1970) ... This characteristic in itself makes marriage formation in these societes difficult to analyse in western categories. Secondly, . . the formation of marriage is not necessarily linked essentially to any ceremonial procedure and may take place in the absence of formalities, notwithstanding the fact that informants may make normative statements linking formation with given ceremonial observance... There is also a tendency to overlook the fact that the distinction between 'marriage' and less approved forms of mating, strongly entrenched in our own system, need not be duplicated elsewhere ... Even where such a distinction is important, there may be a continuum running from most approved to least approved with a very hazy area in the middle of the band ... All of this comes back to the simple point that great care must be taken by the researcher not to invest the form of mating he observes with inappropriate and possibly seriously distorting elements of his own values (Roberts 1977: 7-8). So much for the way in which the 'traditional versus modern legal systems' dichotomy distorts rather than facillitates legal officers' understanding of 'traditional' law. In addition, it hamstrings the legal system in acknowledging changing customs in a rapidly industrialising society, and distorts the way in which legal officers think of the problems with which they are confronted, in preventing a recognition of the development of new institutions that do not fit into either category.

\section{Acknowledging changing customs}

In practice in South Africa what system of law is applied in adjudicating disputes between Africans is decided according to the Native Administration Act of 1927, as subsequently amended. It created a separate court system for Africans, enabled them to bypass the chief's limited local jurisdiction or to appeal from it to the local Native Commissioner, and authorised the courts of Native Commissioners to apply South African Roman Dutch law (the 'common law' of South Africa) or to decide cases that involved African customs 'according to the Native law applying to such customs'. There are two limitations in the section: first, the relevant rule of law must not have been repealed or modified; and second, it must 'not be opposed to the principles of public policy or natural justice'. The dowry or marriage consideration (known by various terms, such as lobola or bodadi, and given for a bride on an - at least potentially polygamous - African law marriage) had at various times in parts of South Africa been declared contrary to public policy, so a further proviso stipulates that 'it shall not be lawful for any court to declare that the custom of lobola or bogadi or other similar custom is repugnant to such principles'.

In effect, this act (and the earlier acts it replaced) created a new form of law, different from the rules of social control which exist or existed in African society and were regarded as binding. As can be seen, the courts recognised only a selection of these rules, and even to these thev made additions and amendments. It could well be argued that the distorted Bantu law (as it was subsequently renamed) which emerged, was a 'modern' legal system. 
On the other hand, it is unclear how far the courts are empowered to recognise changing conditions and customs in African society. The Native Administration Act's authorisation to the courts to decide cases 'according to the Native law applying to such customs' led from an early period to a series of conflicting judgments, even from the same provincial of the $\mathrm{Su}-$ preme Court. In the 1941 case of Phiri v. Nkosi ${ }^{1}$, for example, one judge argued that modifications should be made in divorce proceedings, but was overruled by the majority, who held that there were too many tribalised Africans who would be adversely affected. Two years later, however, in Tyobeka v. Madlewa ${ }^{2}$, the court held that the wife must be made a party to the action for the return of her 'dowry' cattle (an action brought solely by her male guardian in tribal law). This decision was reversed two years later in Mashapo v. Sisane ${ }^{3}$, when the courts declared that this was too great a change in the law and that it had no power to make law. Only the following year, however, in Mokgatle v. Mokgatle ${ }^{4}$, it was held that the wife should be joined with her guardian as co-plaintiff. Given such uncertainty of law and reluctance on the part of the courts to 'act as law-makers', the division of the law into 'traditional' and 'modern' legal systems would not appear to assist Africans placed by the courts in the 'traditional' sector in obtaining recognition of changing customs ${ }^{5}$. The inadequate training for this difficult exercise of discretion by white judges in courts in the 'traditional' sector makes the usefulness of the present courts even more dubious (Suttner, 1968, 1970).

Moreover, the legal system set up by the Native Administration Act is based on an assumption, inherent in the 'traditional versus modern legal systems' dichotomy that legal cases fall into one system or another and that parties would therefore rarely have difficulty in determining whether a matter came under African or Roman Dutch law. A person is believed to operate in either one system or the other. In practice, however, the courts have experienced great difficulty in deciding on the appropriate system of law to be applied in marginal cases. Even confining consideration of their difficulties to only the type of case involved, not the differing backgrounds of the parties, the problem has two facets: there are cases which deal with practices regulated in both African and Roman Dutch law (such as the repayment of loans) and where the courts, as a result, have been uncertain which system of law should be applied; and there are cases which involve a mixture of practices, some governed by only African law and others by only Roman Dutch. In this type of case neither system is totally applicable, and there is no provision for applying a modified mixture of both. A more detailed discussion of both types of cases may serve to highlight the problems.

In deciding which system of law to apply to practices recognised in both systems, the courts had two opposing traditions from South African colonies to guide them. One, inherited from the practices of the Transvaal, Orange Free State, and Cape, assumed that the Roman Dutch law was the basic system and treated African law as a subsidiary one in so far as it recognised it at all. On the other hand, in Natal African law had been the primary system in civil suits between Africans. The Southern Division of the Appeal Court originally upheld the Cape tradition ${ }^{6}$, and there followed a tussle with Judge McLoughlin of the Northern Division, who held that Parliament had intended to apply the Natal rule throughout the coun-

\footnotetext{
11941 N. A. C. (T. \& N.) 94.

21943 N. A. C. (T. \& N.) 60.

31945 N. A. C. (T. \& N.) 57.

41946 N. A. C. (T. \& N.) 82.

5 What alternations the courts have made have in general been retrogressive in their effect on the rights of women, who as a result suffer serious disabilites. See Simons 1968, esp. pp. 83, 92, 187 et seq., 194 et seq., 198 et seq., 202 et seq.

6 Nganoyi v. Njombeni 1930 N. A. C. (C. \& O.) 18.
} 
try. ${ }^{7}$ Later, he became President of the Southern Division of the Court and imposed his theory on the Cape as well. ${ }^{8}$

The determination to place Africans under African law went so far as to attach only African law consequences to actions brought by African women, even when they opted to sue under the Roman Dutch law for delicts not recognised as such in African law. Thus, for exemple, seduction, although recognised as an injury in both systems, is not the same offence, in that in the two systems the injury is believed to be of a different kind and to affect different people. In Roman Dutch law seduction is believed to be an offence against the girl herself, who because of 'the frailty and weakness of women's has been led from the path of virtue, lost her virginity, and suffered the consequent deterioration of her value in the marriage market. ${ }^{10} \mathrm{In}$ the African law view of seduction the idea of an affront to the dignity of the woman is missing, since she agreed to the act. However, 'an unmarried girl "belongs" to her father or his heir, who has a reasonable expectation of receiving dowry for her in due course. When she has been seduced her eligibility for marriage, or marriage value, is depreciated; hence the imposition of a fine or damages is to reimburse her guardian for his prospective loss in dowry' (Seymour 1953). In Roman Dutch law the woman herself has the right to sue for damages for the consequences of the seduction, including lying-in expenses; in African law only the guardian can sue, and damages are estimated in a different way. Yet in various cases such as Lebona v. Ramokone ${ }^{11}$, the court expressed disquiet at African women suing for seduction under the Roman Dutch law and refused to allow them to receive more that their guardians would have been entitled to claim under African law, including, in the case above, refusal to award lying-in expenses and maintenance for a minor child. It required a decision of the Appellate Division of the Supreme Court to untangle this particular confusion of legal systems: that court ruled that a woman is not debarred from succeeding in an action under Roman Dutch law for damages for seduction and that, if she succeeded, her damages were not necessarily limited to the amount that her guardian was entitled to claim under African law. ${ }^{\mathbf{1 2}}$ The decision emphasised that the courts were not entitled to exercise a prima facie preference for African law. But it is not clear to what extent the Commissioners' Courts have abided by the spirit of this decision. ${ }^{13}$

In this case and subsequently ${ }^{\mathbf{1 4}}$ the Appellate Division has recognised that guidelines should be provided to the lower courts to assist them in deciding what system of law to apply. The Appeal Court suggested that the standard of education, the degree of civilisation and detribalisation, and the circumstances of the case, such as the nature of the dispute and its origin, should be considered. In general the court should tend to apply that of law which would provide a remedy, bu this was not an inflexible rule; African law might be followed in certain cases where it appeared to operate more equably than Roman Dutch law. These guidelines, however, beg as many questions as they answer. What is meant by the degree of civilisation? Does it mean acceptance of a western way of living and religion, or an ability to deal with modern technological society? What about cases where one system provides a remedy but is

\footnotetext{
7 E. g. Moima v. Matladi \& ano. 1937 (T. \& N.) 40; Matsheng v. Dhlamini \& ano. 1937 N. A. C. (T. \& N.) 89; Kaula v. Mtimkulu \& ano. 1938 N. A. C. (T. \& N.) 68; Mhlongo \& ano. v. Sibeko 1937 N. A. C. (T. \& N.) 34; Yako v. Beyi 1944 N. A. C. (T. \& N.) 68 8 Sawintshi v. Magidela 1944 N. A. C. (C. \& O.) 47.

9 Spies's Executors v. Beyers 1908 T. S. 477, citing Grotius's Introduction to Dutch Jurisprudence 3.35.8.

10 Carelse v. Estate De Vries 23 S. C. 539; Van der Linden's Institutes of the Laws of Holland (Henry's translation) 251.

111946 N. A. C. (C. \& O.) 14

12Ex parte the Minister of Native Affairs: in re Yako v. Beyi 1948 (1) S. A. 388 (A. D.).

13 See Suttner 1969:626, n. 4. 'The reports of Bantu appeal court decisions have become very much briefer in recenty ears, so that it is difficult to establish exactly how much the discretion is being administered. There is one case, Mtolo v. Poswa [1950, N. A. C. (S. D.)] 253, later dissented from by the Appellate Division in Umvovo v. Umvovo, which definitely misapplied an aspect of the Yako v. Beyi judgment.'

14 Umvovo v. Umvovo 1953 S. A. 195 (A. D.).
} 
considered inappropriate by the other criterial? What about an educated African who enters into a transaction recognised only by African law? The courts have had considerable difficulty attempting to apply these rules.

One area where the confusion has been particularly striking is that where Africans bring to court cases involving a mixture of practices, some recognised only by Roman Dutch law, and some only by African law. Within the latter category are African law marriages - termed customary unions - which are not recognised by the Roman Dutch law as legal marriages. ${ }^{15}$. Urbanisation and Industrialisation in South Africa, complicated as it is by a policy of encouraging migrant labour but preventing a man's family from leaving the 'tribal homeland's with him when he takes up work in towns, has led to the retention of many African customs which habe been combined with Roman Dutch law institutions. One of the most comon combinations of this type is the payment of lobola or bogadi (regarded in Bantu law as one of the essential requirements for a valid African law marriage) on the occasion of a Roman Dutch law marriage. Such dowry payments in fact are usually higher for a Roman Dutch law marriage than for an African law one, since the better educated and more prosperous tend to marry by the former. This combination of Roman Dutch law marriage and dowry payments began over 100 years ago in South Africa, and today almost half of all African marriages in South Africa are Roman Dutch law marriages, with dowry paid in most of them. Since the institution of lobola has always been and remains an integral part of African family law - an important one, as it helps to ensure the husband's good behaviour and also provides a binding link between families and a means for the wife's family in turn to obtain wives - it would seem rational to expect recognition for this combination to have evolved many years ago. However, marrying by Roman Dutch law automatically invokes the application of the Roman Dutch legal system, which does not recognise African law marriages, and an insistence on the 'traditional law versus modern legal systems' dichotomy blockes the possibility of recognising the existing situation for a long time.

Two different lines of argument were used to rationalise the facts that would not fit the dichotomy. One set of judgments laid down that where a dowry agreement had been entered into in consideration of a Roman Dutch law marriage, the parties concerned had, in fact, contracted two concurrent marriages, the one under African law and the other under Roman Dutch law, and that African law was applicable only to the former. ${ }^{16}$ In other decisions it was held that the dowry agreement was ancillary to the Roman Dutch law marriage, but that, nevertheless, African law should apply to the dowry agreement. ${ }^{17}$ This would mean the dowry might be reclaimed in certain circumstances that would not be adequate grounds for ending the Roman Dutch law marriage. Both of these lines of argument ignored the whole purpose of the dowry payment, which was first and foremost to safeguard the wife during the subsistence of the marriage, and to ensure her good behaviour. Yet is was only in the middle of this century, some hundred years after Africans adopted this combination, that the courts made the crucial breakthrough in recognising the purpose of the payments. The third, and now wellestablished opinion is that the dowry agreement is entirely ancillary to the Roman Dutch law marriage ${ }^{\mathbf{1 8}}$; 'the parties to the agreement are deemed to have entended that it should be adjusted to meet the exigencies of the marriage. Thus it is held to be their tacit agreement that the spouses will adhere to the standards and ideals required of them by the mar-

15 Santam v. Fondo 1960 (2) S. A. 467 (A. D.)

16 Gomani v. Baqwa 3 N. A. C. 71; Peme v. Gwele 1941 N. A. C. (C. \& O.) 3.

17 Samson v. Mbanga 1 N. A. C. 217; Manqana v. Ntinintili 1 N. A. C. 218; Kanisa v. Ngodowana 5 N. A. C. 49 ; Somzana v. Bantshi 4 N. A. C. 84.

18 Fuzile v. Ntloko 1944 N. A. C. (C. \& O.) 2; Raphuti v. Memetsi 1946 N. A. C. (T. \& N.) 19; Matchika v. Mngumi 1946 N. A. C. (T. \& N) 78 . 
riage contract' (Seymour 1953:223). Yet even now, after the death of the member of the woman's family who was party to such a dowry agreement, the complicated rules of Bantu law that determine who shall inherit the rights and duties in respect to the dowry appear to be dictated more by a desire to keep the dowry arrangement firmly within the sphere of Bantu law rather than a concern to ensure that they go to the relatives who in practice would be responsible for the woman should the marriage run into difficulties or be ended by the death of the husband.

There are many other similar instances of contradictory decisions by the courts when faced with combinations of African and Roman Dutch law institutions that will not fit neatly into the straitjacket of legal dichotomous thinking. In most cases the courts have not, as in the case of dowry, recognised that an amalgam of the two systems is required to match the changing social circumstances and attitudes of the majority of Africans. There are, of course, enormous problems in doing this: there is no uniformity of African expectations or way of life throughout the country, and the legal requirements of a second- or thirdgeneration urban African are often very different from those of a migrant labourer who returns to his family in a 'tribal homeland' every year. Even within urban areas there are many variations. 'There is no one pattern of urban African life. There are many changing patterns of behaviour within the family, many different adaptations between the traditional and the modern. Income, occupation and education, length of urban residence - quite apart from personal attributes - affect these patterns' (Hellman 1968:7). But it is totally unrealistic to insist therefore that the expectations and way of life of either party in a case will conform to one or other of the two legal systems available, neither of which was developed, or has since been allowed to do so adequately, to meet these needs. The case has occurred, for example where dowry was given for a Roman Dutch law marriage and, on the death of the husband, the dowry remained with the wife's family. As is customary in some tribes, the wife was then taken by a relative of the dead husband in a levirate arrangement in which all parties intended the children of the union to be considered - as is normal in such arrangements - as the children of the dead man. However, when the children subsequently claimed property by virtue of this status, the courts refused to recognise them, ${ }^{19}$ deeming it 'contrary to public policy'. In this type of case the parties to the combination of legal systems are not in dispute as to what their intentions were. It would be productive of greater justice, if more time-consuming, for the courts in such cases at least to investigate what the expectations of the parties were when they entered into such arrangements (irrespective of how well these expectations fit either system separately), rather than to insist that the system of law under which the person is placed dictates all consequences irrespective of his way of life in reality. What would be lost in certainty - and, given the variability of court decisions in many of these areas, this would not be as great as might at first sight be expected - would be made up for in justice. The present system of insisting Africans opt for either 'traditional' or 'modern' law leaves a large number at a disadvantage in either society and, farfrom assisting the legal system to acknowledge the changing customs of a rapidly industrialising society, appears to impede this development of the law.

19 Magcoba v. Magcoba 6 N. A. C. 17. 


\section{Achieving policy aims}

Where the 'traditional versus modern legal system' dichotomy has from an early period proved very useful, however, has been in the sphere of achieving policy aims. From the period of first contact with Africans, the Cape Colony, which ruled the largest number of Africans, was convinced that it should break the tribal system as fast as possible, as it threatened white supremacy and the spread of Christianity as well as interfered with the supply of African labour. Since the power of the chiefs was supported by a complex web of inter-related African institutions, African law was to be abolished as fast as possible - an attitude perfectly compatible with the view, already mentioned, that African law was inferior to Roman Dutch law. The Transvaal and Orange Free State republics took much the same position, although they were determined to enforce segregation whether or not the Africans became 'civilised'. In those districts of both the Cape and the Transvaal where the large number of Africans living according to tribal law made the refusal to recognise it a complete farce, chiefs, magistrates and headmen settled disputes under tribal law but acting as arbitrators and on sufference, since the regular courts refused to sanction the law they administered. In the Transkeian Territories and Natal, for historical reasons and because of the overwhelming number of Africans, it was considered essential that the white administration should exercise control through recognising the tribal law, which was modified in important respects 'for reasons of public policy' to prune it of its 'most serious defects' - by proclamations in the Transkei and by codification in Natal. In all areas, however, the view of the administrations remained clear: Roman Dutch law was the superior system and Africans who 'became civilised' could move out of the sphere of 'traditional' law to the higher plane of the 'modern system'; recognition of traditional law was merely a necessary but temporary concession to the prejudices of primitive peoples.

By the turn of the century, however, he fighting power of the tribes had been broken and tribalism was no longer a threat. Far more disturbing were urbanisation, the separatist church movement, African competition for land, and the emergence of African political associations and an African press. The new elite appeared more menacing than traditional leaders. Young people, now that tribal discipline was declining, no longer showed 'proper respect'. With the decline of polygamy, so offensive to rigid Christian sensibilities, the giving of a marriage consideration lost its wickedness-by-association and was seen to provide a useful incentive to young men to join the labour market. In short, the discovery that African law had unexpected virtues was largely the result, as integration progressed, of the crumbling of the society in which it was based.

With the discovery that it might be not only possible but desirable to perpetuate African law, theold dichotomy of traditional versus modern legal systems was refurbished with new connotations and given a new lease of life. While the dichotomy might still represent a hierarchy, it was no longer one up which all men of every colour would eventually be led; it was, rather, an indication of two separate cultures within which people of the appropriate colour might remain for the foreseeable future, better suited than by attempting to grapple with a culture with which they would be unable to cope. African law should be given priority for Africans subject, of course, to policy constraints to suit the white population - and Africans encouraged to develop along their own lines in their own territories, over which a paternalistic eye would be kept. A blending of the two populations, with their two social and legal systems was to be discouraged.

These attitudes were illustrated in the speeches of the country's leading politicians in 1927, when the Native Administration Act was passed. In the debate 'General Hertzog main- 
tained, and General Smuts agreed, that it had been a mistake, and a great evil, of previous administrations to undermine the power of the chiefs. "We colonials", said Smuts, "thought the native chief was an organ of barbarism". He considered that the "native mind" was very immobile. The "vast mass" were then where they were 100 years ago. "But for the passing away of barbarism and tribal wars, there is no change in the native mind or life" (Simons 1968: 54). The shift in attitudes can be seen as taking the form of a decline of the Victorian optimism especially typical of the missionaries and Cape liberals, which foresaw the change in African life-style taking place within a generation or two; instead the dominant national view of the African was becoming that of a people so primitive as to be unable to 'catch up' with 'modern' society within the foreseeable future. The timespan between the 'traditional' and 'modern' legal systems was being elongated.

Meanwhile, however, the attitudes which had given rise to the earlier policy did not vanish overnight. The legislation in 1927 on which the above speeches were made and which introduced a uniform policy on African law to replace provincial variations - the Native Administration Act of 1927 - was modelled on the Transkeian policy of flexibility to allow adaptation as Africans became 'civilised'. However, as pointed out above, until 1948 judicial interpretation of the law pushed it increasingly towards greater emphasis being put on African law as the primary system to be applied, to the exclusion of Roman Dutch law. Since then the Nationalist Government's policies have at least indirectly encouraged the continuance of African law.

The point on which policy was much clearer was the need to discourage Africans from entering the national political or social arena. The Native Administration Act therefore embodies a (historically inaccurate) view of the powers of a paramount chief for controlling his subjects. The Governor-General was made the supreme chief of all Africans, and given extensive powers not, in fact, exercised by tribal chiefs. These powers were, however, subsequently even further extended. ${ }^{20}$ ' $\mathrm{He}$ can appoint and depose chiefs, divide or amalgamate tribes, deport banish tribal groups or individuals, and legislate by decree for the scheduled native areas' (Simons 1968: 53). The act also created a separate court system, made up of Chiefs' and Native Commissioners' courts and a Native Appeal Court, later renamed Bantu Courts. ${ }^{21} \mathrm{~A}$ separate Native Divorce Court was subsequently established by Act 9 of 1929. From the Appeal Court there are limited possibilities of appeal to the Appellate Division of the Supreme Court (Suttner 1970: 143). The way in which the white administration and courts were put at the head of African society, with the Governor-General designated the 'Supreme Chief', make the model in use clear. It was not - and given the white society's requirements of it, could not be - that of two separate legal systems of equal validity and merit; a hierarchy was required, and the 'traditional versus modern legal systems' conceptualisation served the administration very well. It also had the added advantage of being self-fulfilling to some extent, since it helped to keep the Africans tied to a 'tribal' system.

Over time not only has the separate administration and further application of African law been increasingly emphasised; the use of 'tribal authorities' as means of control has been strengthened. Simons (1968) spells out the history of the expansion of the 'supreme chief's' powers of banishment, and deals with the subsequent extension of these powers to African chiefs.

Originating in a spurious version of tribal rule, the supreme chief doctrine has moved full circle by recreating chief tainship in its own image. A proclamation of $1960^{22}$ enables

20 By Section 2 of Act 42 of 1956.

21 By Section 16 of Act 46 of 1962 'Bantu' was substituted for 'Native'.

22 Regulations made under proclamation R. 400, 1960 (Simons' note). 
the minister to delegate the power of banishment to any chief in the Transkei. An authorised chief may order, without prior notice, the removal of a person, with his family, goods and chattels to any specified place in the tribal territory; and may order the demolition without compensation, of the banished family's hut or dwelling. An appeal may be brought against a removal order to the chief commissioner, whose decision is final. (Simons 1968: 57)

It may be questioned whether African tribal society operated according to an underlying idea of the rule of law in the sense of an immanent body of principle to which reference might be made in order that the affairs of men might be governed with justice and certainty. However, it is known that in southern Africa tribal society arbitrary rule was the exception, despite the notorious example of certain Zulu chiefs.

The executive's power to banish for an indefinite period and without trial or recourse to the courts is characteristic of a colonial society, and not of the traditional tribe. A chief in the days of tribal self-rule depended on the general body of tribesmen for his armed force. He was responsible to his councillors and people. Coercion would stretch no further than their consent. He ran the risk of being deposed or assassinated if he abused his authority beyond the point of their endurance. These sanctions no longer apply. Power now comes from above and is absolute. (Simons 1968: 57-8)

And this resulted from an insistence that the 'modern legal system' is totally inapplicable to 'traditional' society, even though that society has been changed to such an extent that it no longer has built-in safeguards of its own. Its members now need protection from some other source, but this is refused while they are placed under the 'traditional legal system', from which, in theory, it will be a very long time before they are all fit to 'rise'.

Adverse African reaction to this system and the chiefs administering it was therefore hardly surprising.

Their courts were regarded by their opponents as instruments of partiality and coercion rather than as the means of reconciling parties and asserting tribal unity; they enforced the white man's policies without the restraints which operated in white man's courts, and their judgements generated rather than reduced social friction. (Sachs 1973: 117)

The extent of African rejection may be gauged by the fact that in 1960, when civil war broke out in eastern Pondoland, a very 'traditional' area, wherever the rebels gained control popular courts were set up in opposition to those of the chiefs until the South African government reasserted its control. (Mbeki 1964: Chap. 9).

\section{Conclusion}

It would therefore seem that the conceptualisation of legal systems as 'traditional' versus 'modern' has in general not served the African population of South African well, although it has proved useful to the white administration. For ideological reasons, both those inherent in the conceptualisation and those inherent in South African society, the 'traditional law' as defined in South Africa has not proved congruent with the customs of the 'traditional' section of the society to which it was applied. Even more important, however, is the fact that the way of life of Africans in South Africa is no longer, in general, 'traditional' in any sense except by policy definition. African life-styles now vary greatly. To try to force on them the legal straitjacket of the 'traditional versus modern' dichotomy is grossly to distort both the facts and their lives. It remains to be asked whether the 'traditional versus modern legal systems' model may not have a predictive value for South Africa were the African population 
able to influence legislation more directly. To phrase this another way, Gluckman argued that 'traditional legal systems' were an expression of a pre-industrial way of life, dominated by the need to maintain multiplex relations and certain status relations. Might it therefore be argued that the development of 'modern' (that is western) legal systems could be an indication of the inevitable path of development of an African-controlled legal system as the rural population is increasingly affected by industrialisation?

Even assuming a controlling African population that favoured a capitalist economy, the answer to this question, I would suggest, is that any predictions based on the development of 'modern' legal systems could only be of so general a nature as to be virtually useless for all practical purposes. Weber pointed out that the development of the particular systems of law that appeared in the West was closely related both to political history and to the requirements of capitalistic enterprise (1954: 224, 267, 304-5). He reviewed the variety of types of legal development in the Occident and argued that even in the west the development of the legal system to match the greater bureaucracy of the administration took many forms.

All these events have to a very large extent been caused by concrete political factors which have only the remotest analogies elsewhere in the world ... Economic conditions have, as we have seen, everywhere played an important role, but they have nowhere been decisive alone and by themselves. (Weber 1954: 304-5)

The cultural background and historical experience of the African peoples of South Africa has, even in the recent past, been so different from that of the west that it is highly questionable whether the phenomenon of industrialisation automatically makes possible the prediction of given changes in the legal system, except of the most general kind. This is particularly true since the growth of a world economy has involved differential effects on the economies and state development of heavily industrialised and relatively unindustrialised economies. Even in African societies today that have deliberately imitated and adopted western enonomic institutions and legislation, research is showing how varied and of ten unintended is the actual, as opposed to theoretical, operation of their legal systems, both substantively and procedurally (e. g. Harrell-Bond 1975, Roberts 1977). This type of work, paralleling disillusions with the economic predictions of the development theorists, is leading to greater scepticism of the extent to which governments can predict or direct social change on the basis of any model. As Sally Moore argues (1978: 1),

the same social processes that prevent the total regulation of a society also reshape and transform efforts at partial regulation. The making of rules and social and symbolic order is a human industry matched only by the manipulation, circumvention, remaking, replacing, and unmaking of rules and symbols in which people seem almost equally engaged. There is a basic tension between the idea that law epitomises manmade, intentional action, and constitutes the means by which a conscious and rational attempt to direct society can be undertaken, and most thought in the social sciences, that there are underlying causes of social behaviour which are not fully in the conscious control of the actors, yet which are the core of what the social scientist studies.

Rather than attempting to find some alternative to the modernisation model, the more constructive immediate course of action would appear to be that of meeting the need for more research on actual legal systems. Study is required not only of the functioning of legal systems in practice, but of both the conscious and underlying interests, values, and objectives of legal systems, and the way in which these change, in the setting of the changing society and world economic system in which they have functioned and still operate. This is far more likely than existing modernisation models to facilitate an understanding of the way the systems work 
and their probable future development. Such studies, paralleling the type of research in economics and politics suggested by Wallerstein (1976), should in the future generate a more useful model than that of 'modern' versus 'traditional' legal systems.

\section{References}

Bohannan, P.

(1963) Social Anthropology, New York, Holt, Rinehart and Winston.

Cohen, P. S. (1967), 'Economic Analysis and Economic Man' in Themes in Economic Anthropology, ed. R. Firth, London, Tavistock.

Gluckman, M. $\quad(1955 ; 1967)$ The Judicial Process among the Barotse of Northern Rhodesia, Manchester, Manchester University Press.

(1955 a) The Ideas in Barotse Jurisprudence, New Haven, Connecticut, Yale University Press.

(1965 b) Politics, Law and Ritual in Tribal Society, Chicago, Aldine Press.

Harrell-Bond, B. E. (1975) Modern Marriage in Sierra Leone: A Study of The Professional Group, the Hague, Mouton.

Hellmann, E. (1968) 'The African Family Today', African Family Life, Symposium published by the South African Institute of Race Relations.

Hoebel, E. A. (1954)TheLaw of Primitive Man, Cambridge, Mass., Harvard University Press.

Lloyd, D. $\quad$ (ed.) (1965) Introduction to Jurisprudence, London, Stevens.

Mbeki G. (1964) South Africa, The Peasants' Revolt, Harmondsworth, Penguin.

Moore, S. F. (1978) Law of Process: An Anthropological Approach, London, Routledge and Kegan Paul.

Nader, L. $\quad$ (ed.) (1969) Law and Culture in Society, Cicago, Aldine Press.

Paton, G. W. $\quad$ (1951) Jurisprudence, London, Oxford University Press.

Roberts, S. A. (ed.) (1977) Law and the Family in Africa, The Hague, Mouton.

Sachs, A. (1973) Justice in South Africa, London, Heinemann. 
Seymour, S. M. (1953) Native Law in South Africa, Cape Town, Juta \& Co.

Simons, H. J. (1968) African Women: Their Legal Status in South Africa, London, C. Hurst \& Co.

Suttner, R. S. (1968) 'Towards Judicial and Legal Integration in South Africa', South African Law Journal, Vol. LXXXV (Part IV), November.

(1969) 'The Legal Status of African Women in South Africa', African Social Research, Vol. 8, December.

(1970) 'Legal Pluralism in South Africa', The International and Comparative Law Quarterly, January.

Wallerstein, I. (1976) 'Modernization: Requiescat in Pace' in The Uses of Controversy in Sociology eds. L. A. Coser and O. N. Larsen, New York, The Free Press.

Weber, M. $\quad(1925 ; 1954)$ On Law in Economy and Society tr. E. Shils and M. Rheinstein, New York, Simon \& Schuster, 1954. 


\title{
Kandyan Law and British Colonial Law: A Conflict of Tradition and Modernity - An Early Stage of Colonial Development in Sri Lanka
}

\author{
By M. L. MARASINGHE
}

The article is intended to consider the problems of association between two types of legal systems based upon very different assumptions. The conquest of the Kandyan Kingdom brought about the acquisition of a sizeable land mass by the British, in Ceylon, inheriting a legal system based on certain Ethno-social and Religio-Cultural assumptions. The task of the British government was essentially one of reconciling some of the fundamental assumptions of the English Common Law with those of the Kandyan Law. The inequality in the application of the rules of law, the recognition of social stratification upon caste lines, the legalisation of torture and the recognition of Buddhism as the only lawful faith in the kingdom were some of the fundamental characteristics of the law and its institutions. The way by which the British government succeeded in assimilating such a system results in the modernization of a whole system of laws and institutions of a traditional legal system. This naturally creates a number of difficult socio-political problems. The article forms a part of a book on Law and Modernization in Sri Lanka which is presently been written by the author.

\section{Use and Abuse of the "Modern" versus "Traditional" Law-Dichotomy in South Africa}

\section{By SANDra Burman}

This paper discusses whether it is useful to categorise multi-cultural societies as either traditional or modern, with specific reference to the South African situation where this categorisation has been used for over a century. The distortions it introduces in the approach of legal officers to indigenous legal systems, and the difficulties it has led to in South Africa in acknowledging changing customs are examined in relation to current anthropological debates and court cases. Its role in enabling South Africa's policy makers to achieve certain policy goals is then analysed in an historical framework, and the paper concludes with a discussion of whether the dichotomy might be useful in predicting the course of future legal development in South Africa were the African population to have greater control of their legal system.

\section{Unité du Droit ou Diversité du Droit}

\section{By E. A. B. van Rouveroy van Nieuwaal}

The most complex questions for the African legislator are still the problems of adaptation, reform and integration of different laws into one national law system. These problems vary from country to country, from region to region even, due to a different social and economic development, but nearly always in a very fast way. They are increased by the colonial inheritance of diversity of law and culture. Most African governments decided after the Indepen- 